\title{
Komunikacyjna rola przedogródka, czyli rzecz o ludowej wizji świata
}

\section{W miejsce wstępu}

U nas we wsi jest taki zwyczaj, że w noc wigilijną gospodarz wychodzi do ogrodu i siekierą bije lekko drzewa owocowe i przy każdym powiada: „Zetnę cię, bo nie rodzisz”. Czasem grozi: „Jak nie będziesz rodzić, to cię zetnę”. A syn gospodarza, abo jego kobieta, stoi za drzewem i odpowiada: „Oj, nie ścinaj, nie ścinaj, bo już będziemy rodzić". A mało kto wie, że kiedyś drzewa noprowda godały ludzkim głosem. Moja starka opowiadała, że raz jeden gospodarz poszedt do lasu i chciał narąbać drzewa na opał, bo zima była siarczysta, a polić nie było czym. [...] No i chłop wraca z lasu bez drzewa. Zimno, chałpa zimno, dzieci płaczą, ale co robić? W tym dźwierze się otwierają i wchodzi zmarznięty gość. Powiada: „Czy pozwolicie mi się u was ogrzać?”. A chłop na to: „Chętnie byśmy ci pozwolili, ale my sami marzniemy. Byłem w lesie po drzewo, ale wszystkie tak mnie prosity, aby ich nie zetnąć, że mi tak żal było, żech je zostawit. Płakały i wołały, że i im serca pękają, a przez ich krew i duszę, moje drzewo będzie mokre i że się i tak nie rozpali!” Wtedy staruszek poszedł z nim do lasu i zawołał: „Na moje wezwanie wszystkie drzewa od tej chwili przestaniecie godać ludzkim głosem, a serca i dusze biera do siebie", bo wiecie, to był sam Pan Jezus (Simonides, 2010: 111).

Zacytowany fragment opowiadania Dlaczego drzewa przestały mówić? zaczerpnęłam z książki Doroty Simonides. Autorka podejmuje w niej próbę odtworzenia ludowej wizji świata, przytaczając wiele mitów, legend i baśni przekazywanych z pokolenia na pokolenie przez mieszkańców słowiańskich wsi. Przybliżając strukturę antropologiczno-kulturową dawnego ludu, wskazuje między innymi na odwieczny związek człowieka z naturą. Przypomina, że przyroda, a więc drzewa, krzewy i rośliny zielone niejednokrotnie były antropomorfizowane, a nawet miały „charakter transcendencji, a zatem wymagały kultu i stanowity sacrum” (Simonides, 2010: 7). Dzięki swojej wszechobecności w sferze religii i magii, a więc zarówno w obrzędach 
chrześcijańskich, jak i w wierzeniach sięgających swoimi korzeniami pogaństwa, odgrywały decydującą rolę w kulturze ludowej.

Według gminnych przekonań świat roślin zatracił umiejętność mówienia ludzkim głosem, w żadnym jednak razie porozumiewania się nie zaprzestał. Wiara w magiczną moc roślinności przetrwała na polskiej wsi do początków XX wieku. Z czasem ich symboliczne znaczenie i funkcja mediatorów, którą pełniły, oscylując między światem ludzkim i nieludzkim, uległy przekształceniu. Flora przestała komunikować się z człowiekiem, porzucając tworzone między nim a sobą różnego rodzaju relacje, a zaczęła komunikować określone treści, których autorem przestał być przedstawiciel „tamtego" świata, a stał się drugi człowiek.

Niniejszy artykuł stanowi próbę stworzenia modelu, na podstawie którego możliwe stanie się opisywanie, w tym klasyfikowanie, ogromnego i doniosłego (nie tylko dla folklorystów), komunikacyjnego potencjału natury. Już wybiórcza i niezwykle pobieżna analiza materiału, przeprowadzona z perspektywy komunikatywizmu, zdaje się potwierdzać zasadność rozszerzenia pojęcia aktu komunikacji. Współcześnie przyjmuje się, iż „akt komunikowania jako akt przekazania lub odebrania informacji może się dokonać nie tylko między ludźmi, nie tylko między człowiekiem a zwierzęciem, ale także między człowiekiem a maszyną, a nawet między dwiema maszynami" (Pisarek, 2008: 17). Uzupełnienie go o kolejną możliwość: roślina - człowiek, otwiera nowe perspektywy badawcze przed przedstawicielami co najmniej kilku dyscyplin naukowych (językoznawstwa, literaturoznawstwa, nauk o kulturze i religii czy też nauk o sztuce).

\section{Inspiracje badawcze}

Bezpośrednią motywacją do napisania niniejszego tekstu stał się projekt tódzkiego Ogrodu Botanicznego, obejmujący szeroko zakrojony plan ksztatcenia ekologicznego. W ramach przedsięwzięcia została odtworzona zabytkowa zagroda z przełomu XIX i XX wieku, na której tle spacerowicze mogą podziwiać trzy odrębne kolekcje roślinne. Dwuizbowa chałupa pełni funkcję muzealno-wystawienniczą, a w jej wnętrzu odbywają się zajęcia edukacyjne. W obydwu izbach budynku są ekspozycje etnograficzne ukazujące wygląd dawnego domostwa oraz sprzęt wykorzystywany na co dzień przez gospodarzy, w tym przedmioty drewniane służące do przetwarzania roślin w celach użytkowych. Zagroda wizualizuje związek, jaki istniał między dawnymi mieszkańcami wsi a przyrodą, zwłaszcza roślinami uprawianymi w ogródkach przydomowych i sadzie. Zabytkowej chałupie towarzyszy drewniana stodoła i kamienna obórka oraz oryginalne elementy wyposażenia gospodarskiego: 
studnia z żurawiem i płot pleciony z wierzbowych gałązek. W edukacyjnej kolekcji roślin znajdują się gatunki i odmiany roślin ozdobnych, użytkowych i sadowniczych, usytuowane w trzech odrębnych częściach ogrodu: przedogródku, ogrodzie warzywnym i tradycyjnym sadzie z wysokopiennymi odmianami jabłoni.

Tym, co w szczególny sposób zwraca moją uwagę, jest przedogródek, a właściwie liczne funkcje, jakie pełnit on w wiejskiej zagrodzie. Był on usytuowany przed frontową ścianą chałupy i przeznaczony dla roślin ozdobnych - jednorocznych, bylin oraz krzewów. Odtworzony w Skansenie Roślinnym zachował główne cechy dziewiętnastowiecznych ogródków, takie jak: charakterystyczne rozmieszczenie rabatek, układ ścieżek, dobór roślin i obecność naturalnych kompozycji. Rosną w nim między innymi: aksamitki, astry, bzy czarne, bratki, bukszpany, bylice, chryzantemy, cynie, dalie, dziurawce, dzwonki, floksy, goździki, hortensje, irysy, jaśminowce, kaliny, konwalie, krwawniki, lewkonie, lilaki, maciejki, maki, malwy, mieczyki, nagietki, narcyzy, nasturcje, niezapominajki, ostróżki, pierwiosnki, piwonie, rozchodniki, róże, słoneczniki, stokrotki, tojady, tulipany, wilczomlecze i złocienie. Zgromadzone są one na stosunkowo niewielkiej powierzchni (około $52 \mathrm{~m}^{2}$ ) i odtwarzają malowniczy klimat tradycyjnej polskiej wsi.

Przedogródek w łódzkim Ogrodzie Botanicznym pełni funkcję naturalnej ekspozycji, na bazie której prowadzone są zajęcia edukacyjne nawiązujące do walorów dawnych ogródków, w tym ich wartości ekologicznych, przyrodniczych, kulturowych, historycznych, dekoracyjnych oraz funkcji związanych z kultem religijnym i tradycją. Inną - choć niewerbalizowaną wprost przez twórców Skansenu Roślinnego - funkcją projektu jest odmitologizowanie polskiej wsi, zerwanie ze stereotypowym wyobrażeniem chłopa jako prymitywnego, zacofanego nędzarza, gdyż zgodnie z myślą Claude’a Levi-Straussa: „prymitywizm ekonomiczny nie jest związany koniecznie z prymitywizmem umysłowym" (za: Tomiccy, 1975: 10). Ludowa wizja świata, przejawiająca się w przestrzeni przydomowych ogródków, była spójnym, harmonijnym wyobrażeniem zastałej rzeczywistości. Świadczyła „o wrażliwości estetycznej ludu, a zwłaszcza o odczuwaniu przezeń piękna przyrody" (Moszyński, 1939: 733), o umiejętności wykorzystania właściwości leczniczych roślin, ale ponad wszystko była wyrazem głębokiej kontemplacji natury, pozwalającej na nieprzypadkowe przypisanie poszczególnym gatunkom właściwości magicznych. Zdaniem Kazimierza Moszyńskiego można z łatwością dowieść, że podstawowym celem kultury materialnej ludu wiejskiego było ułatwienie egzystencji. Cel ten zaś stanowił podświadomy bodziec, powołujący do życia wiele przejawów kultury duchowej (Moszyński, 1939: 723). Wydaje się, że praktyki kulturowe i magiczne obrzędy, choć same odwołujące się do pozaludzkiego świata, były zakorzenione w tym, co dostępne dla intelektu. Innymi słowy, z funkcji 
estetycznej i użytkowej roślin wyłaniała się funkcja magiczna, przejawiająca się między innymi w przypisywanej powszechnie roślinom zdolności do komunikowania się z człowiekiem.

\section{Kultura materialna i duchowa tradycyjnego przedogródka}

W ludowym postrzeganiu świata rzeczywistość - zarówno ta dostępna postrzeganiu zmysłowemu, jak i ta ukryta przed zmysłami - tworzyła harmonijną całość, wiążącą człowieka z naturą „wieloma nićmi współzależności” (Tomiccy, 1975: 147). Jak już pisałam, przyroda obecna na co dzień w sposobie myślenia i funkcjonowania wiejskiej społeczności, stanowiła nie tylko istotny element kultury materialnej, ale również łączyła się ze sferą kultury duchowej. Przez wieki kształtowat się emocjonalny stosunek do poszczególnych gatunków drzew, krzewów, bylin i ziót, będący wyrazem głęboko zakorzenionej w pierwotnej umysłowości potrzeby oswojenia tych sfer życia, które wymykały się racjonalnemu poznaniu. Z tego też powodu rośliny bardzo często stawały się „przedmiotem ekspresji magicznej, wierzeniowej, obrzędowej czy religijnej” (Szary, 2015: 5-6). Zdaniem Joanny i Ryszarda Tomickich ten wyraz „niewyczerpalnej, uniwersalnej dążności do nadawania wszystkim zjawiskom sensu" i celu jest specyficzny dla światopoglądu ludowego (Tomiccy, 1975: 151). W społecznościach tradycyjnych ludziom towarzyszyło „mgliste poczucie” (Moszyński, 1934: 528), iż otaczająca ich rzeczywistość jest „tworem sakralnym, w znaczeniu boskim, ale i oswojonym, bliskim, rodzinnym" (Simonides, 2015: 9), tylko to bowiem, co znane, nie było wrogie. Słuszną uwagę na ten temat poczynił dziewiętnastowieczny folklorysta Karol Matyas:

W siole naszym wszystko żyje tajemniczym jakimś życiem, wszystko ma swój początek, swe znaczenie, swą tajemnicę. Spytaj chłopa o drzewo, które rośnie przy drodze lub o kamień, o który potrąci nogą [...] chłop na to pytanie zaraz da odpowiedź (Simonides, 2015: 10).

Wyjątkowy związek liścia, łodygi i korzenia z ciałem, umysłem i duszą rozpoczynał się już w najbliższej człowiekowi przestrzeni przedogródka, stanowiącego dumę każdego domu. Naturalne piękno przydomowych ogródków przynosiło autentyczną satysfakcję estetyczną i świadczyło o postawie gospodyni, spontanicznie szanującej piękno przyrody i strzegącej go. Ponadto pełniły one w życiu wiejskiej ludności wiele funkcji społeczno-towarzyskich. Ich zasobność i urozmaicenie, podobnie jak wyposażenie wnętrza chaty, było wyznacznikiem statusu 
gospodarzy, a gatunki roślin i porządek ich sadzenia przekazywały informacje o rodzinie zamieszkującej dom.

Na niewielkiej przestrzeni między domem a drogą kobiety sadziły liczne gatunki krzewów, kwiatów i ziót. Kontrastowo zestawione rośliny, pozyskane pierwotnie z lasu i łąki, były otaczane najczęściej niskimi płotami plecionymi z leszczynowych bądź wiklinowych gałęzi. Budując ogrodzenie, kierowano się względami praktycznymi, gdyż płot z jednej strony miał zapobiegać wchodzeniu zwierząt na rabaty i niszczeniu roślin, z drugiej zaś miał nie zasłaniać przechodniom widoku uprawianych roślin. Małe ogródki obsadzano grupami roślin o podobnej wysokości. W większych ogrodach wysokie rośliny sadzono pod oknem, w narożnikach i przy płocie, a niskie pośrodku rabat. W obu przypadkach dobierano rośliny o zdecydowanej kolorystyce, różnorodnych kształtach i urzekającym zapachu. Występowanie dużej liczby gatunków i odmian bylin oraz roślin sezonowych powodowało, że okres kwitnienia jednych zazębiał się z czasem kwitnienia drugich. Dawało to efekt przewijających się jak w kalejdoskopie barw przez cały sezon wegetacyjny (Sadowska, Winkler, 2015).

Rośliny znajdujące się w przedogródku stanowity istotny element regionalnego lecznictwa, jak również odgrywały ważną rolę w tradycyjnych obrzędach i wierzeniach ludowych. Niemal każda gospodyni znała się na leczniczych właściwościach roślin i dysponowała swoją „podręczną apteczką". Niemniej w sytuacji, gdy chory nie mógł znaleźć przyczyny swoich dolegliwości, udawał się po poradę do wiedźmy. W wielu bowiem przypadkach uznawano, że choroba jest wynikiem złej woli czarownicy, rzuconego uroku lub czaru i wówczas same zioła nie starczały, należało przejść rytuał odczynienia (Koprowska-Głowacka, 2016: 109). Elementy magiczne i realna użyteczność roślin ulegały w obrębie ludowej kultury pełnemu zespoleniu. Medycyna ludowa posługiwała się roślinami, wykorzystując nie tylko ich własności medyczne. Często rośliny o właściwościach typowo leczniczych, rzeczywiście pomagające na różne schorzenia, były stosowane jako dodatek czy wręcz rekwizyt podczas tajemniczego rytuału unicestwiania choroby. Być może nawet ważniejsze dla chorego i jego otoczenia były gesty i słowa niż terapia dobroczynnymi ziołami (Zadrożyńska, 1985: 22-23).

Zachowane do dzisiaj w pamięci mieszkańców polskich wsi, jak również skrzętnie odnotowane przez etnografów minionego stulecia właściwości omawianych roślin często wzajemnie się wykluczają, są nie do końca jasne, trudno uzasadnić ich racjonalność bądź wskazać pochodzenie związanych z nimi przesądów. Jak pisał Moszyński: 


\begin{abstract}
[...] praktyki, obrządki i wierzenia, osnuwające się dokoła nich [...] są tak wielostronne, zahaczają o tyle przejawów życia, że pomimo licznych i gruntownych studjów [...] do dziś dnia badacze nie orjentują się całkiem jasno w tej gmatwaninie różnorodnych i różnowiecznych nawarstwień, nawiązań i wykolejeń, jaką owe obrządki i wierzenia przedstawiają (Moszyński, 1934: 520).
\end{abstract}

Interdyscyplinarny system klasyfikacyjny roślinności o ile nie umożliwitby rozplątania owej „gmatwaniny różnorodnych i różnowiecznych nawarstwień”, to z pewnością przybliżyłby badaczy do holistycznego spojrzenia na liczne zależności między światem natury a człowiekiem. Narzędzie, czy nawet szerzej - metoda, to dzieło przyszłości. W tym miejscu pragnę jedynie zaproponować wprowadzenie do analiz badawczych pojęcia „ludowa kompetencja”, która w moim przekonaniu stanowi jeden z komponentów kompetencji komunikacyjnej.

\title{
Ludowa kompetencja komunikacyjna na przykładzie tradycyjnego ogródka przydomowego
}

\section{Założenia teoretyczne}

Pojawienie się w połowie lat sześćdziesiątych ubiegłego wieku prac Noama Chomsky'ego, w których po raz pierwszy nakreślony został problem kompetencji, wywotało duże zainteresowanie procesem szeroko rozumianej umiejętności świadomego przekazywania informacji. Autor gramatyki generatywnej pojęcie kompetencji ograniczył do refleksji na temat reguł gramatycznych i słownika, wychodząc z założenia, iż w ten sposób zdefiniowany zakres badań jest wystarczający z punktu widzenia językoznawcy. Nie dostrzegał potrzeby rozszerzania pojęcia kompetencji językowej przez uzupełnienie jej o realia społeczne czy wartości kulturowe, dla niego bowiem umiejętność twórczego posługiwania się językiem miała swe źródła w dziedziczonych z pokolenia na pokolenie uniwersalnych właściwościach ludzkiego umysłu. Dwa lata później, w 1968 roku, amerykański socjolingwista Dell Hymes opracował znacznie szersze pojęcie kompetencji komunikacyjnej, wykazując niedoskonałości, ale i atrakcyjność koncepcji Chomsky'ego (Pisarek, 2008: 63-76). Potraktował on kompetencję językową jako istotny składnik kompetencji komunikacyjnej, w której obok zdolności do użycia określonych środków językowych znalazły się również środki pozajęzykowe, uzależnione od sytuacji komunikacyjnej. Biegłość w skutecznym komunikowaniu się w danym języku została wzbogacona o zachowania mimiczne, kinezytyczne i proksemiczne oraz o percepcję 
czasu i przestrzeni, każdorazowo pozostające w związku z konkretną sytuacją, określaną przez:

[...] okoliczności, czas i miejsce aktu komunikacji, cechy nadawcy (mówiącego lub piszącego), grane przez niego role społeczne, jego poglądy, uznawany przez niego system wartości, właściwości osób, do których jego wypowiedź jest kierowana oraz relacje między osobą mówiącą lub piszącą a osobą (osobami) słuchającymi lub czytającymi (Pisarek, 2008: 64).

Wielostronne spojrzenie na proces porozumiewania się rozbudziło nadzieje na rozwój całkiem nowych perspektyw badawczych, mierzących się z realnymi procesami komunikacji międzyludzkiej. Nadzieje te były uzasadnione, już wkrótce bowiem zapanowała niejako „moda” na opis komunikacji z perspektywy kompetencji. W najnowszej literaturze przedmiotu jako podstawowe konstrukty kompetencji wymieniane są: kompetencja językowa, komunikacyjna, kulturowa, społeczna, ekonomiczna, interpersonalna, interakcyjna, etyczna, literacka, religijna (czy szerzej duchowa) i zyskująca coraz większą popularność kompetencja medialna (Marcyński, 2017: 37-88). Naturalnie lista obszarów/rodzajów kompetencji nie jest zamknięta. Pojawiają się coraz to nowsze terminy odnoszące się do wybranych aspektów komunikowania, rozumianego jako przenoszenie informacji (znaczeń) niekoniecznie zakodowanych w języku naturalnym.

Podążając za tym trendem, pragnę zaproponować inkluzję ludowej kompetencji komunikacyjnej w obręb kompetencji komunikacyjnej. Wychodząc z założenia, iż kompetencja komunikacyjna jest „złożonym zbiorem różnych umiejętności produkcji i interpretacji przekazów" (Awdiejew, Habrajska, 2012: 178), zakładam jej dyferencjalność. Uwydatnienie różnic w indywidualnych zdolnościach i umiejętnościach wykorzystywania okoliczności sprzyjających komunikacji (Pisarek, 2008: 63) jest w moim odczuciu jednym z celów współczesnej nauki o komunikowaniu.

O ile badacze zgodni są co do tego, że kompetencja językowa jest istotną częścią kompetencji komunikacyjnej, o tyle już określenie relacji między kompetencją komunikacyjną a kompetencją kulturową pozostaje kwestią sporną. Dla komunikologów „kompetencja kulturowa jest tylko bardzo ważnym składnikiem kompetencji komunikacyjnej porozumiewających się ze sobą partnerów" (Pisarek, 2008: 71), a nie odrębnym, niezależnym pojęciem. W jej skład wchodzi znajomość zarówno norm komunikatywnych, jak i kulturowych, w tym językowych. Według Walerego Pisarka kompetencja kulturowa to: 
[...] znajomość właściwego danej kulturze symbolicznego znaczenia i aksjologicznego nacechowania elementów postrzeganej rzeczywistości oraz zdolność do świadomego zachowania się wobec nich zgodnie $z$ ich znaczeniem i nacechowaniem, a więc do zachowania - w kategoriach tej kultury sensownego i sprawiedliwego (Pisarek, 2008: 75).

Niezwykle istotne w tym przypadku jest to, jakie znaczenie przypiszemy pojęciu kultury. Na potrzeby moich badań przyjmuję, że:

[...] kultura składa się z trwałych wzorów myślenia, wartości i zachowań, które określają grupę ludzi. Obejmuje przekonania i poglądy ludzi na temat świata, ich duchowość, rozumienie statusu i hierarchii, wykorzystywanie czasu i przestrzeni fizycznej oraz wzajemne związki. Reprezentuje zbiór umysłowych i behawioralnych wzorów, które dają ludziom poczucie przynależności do grupy lub społeczności, traktowanej przez jej członków jako różniącą się od innych grup. Kultura jest zawsze obecna jako tło wszystkiego, co robimy oraz tego, jak widzimy siebie i innych (Morreale, Spitzberg, Barge, 2008: 80).

Takie ujęcie problemu uprawnia mnie do stwierdzenia, iż kompetencji kulturowych jest tyle, ile odmian kultury. Możemy zatem (by wymienić choć kilka) mówić o kompetencji narodowej, religijnej, zawodowej i pokoleniowej, kompetencji związanej z płcią lub seksualnością człowieka (Pisarek, 2008: 71) czy wreszcie o kompetencji związanej z miejscem urodzenia, wychowania i zamieszkania, a wśród nich o ludowej kompetencji komunikacyjnej.

Ludowa kompetencja, jak każda inna, obfituje w wiele zachowań komunikacyjnych (werbalnych i pozawerbalnych), wykorzystywanych do osiągnięcia złożonych celów w sposób, który jest stosowny do kontekstu (Morreale, Spitzberg, Barge, 2008: 87). Wśród nich poczesne miejsce zajmuje roślinność uprawiana w tradycyjnej zagrodzie, szczególnie jej rola społeczno-kulturowa. O komunikacyjnej roli ogrodów wspomina między innymi w publikacji Kompetencja komunikacyjna. Studium medioznawcze Krzysztof Marcyński (2017: 73).

Roślinność sadzona w pobliżu domostw realizowała większość z celów komunikowania wyodrębnionych i opisanych przez Andrzeja Wiszniewskiego: przekazywała informacje, prezentowała gospodarzy, inicjowała związki z innymi ludźmi, zapewniała przyjemność i spokój ducha, a nawet wpływała na postępowanie gospodarzy (por. Wiszniewski, 2003). Mimo iż w pansemiotycznym ujęciu kultury wszystkie zachowania człowieka mają znaczący charakter, powyższa teza może brzmieć dość odważnie. Aby jej dowieść, proponuję opisanie roli komunikacyjnej 
roślinności z przedogródka na podstawie modelu ludowej kompetencji komunikacyjnej. Oczywiście nie wszystkie elementy ogródków przydomowych i procesy w nich zachodzące były postrzegane jako przekaz. Zaproponowany model pomaga jedynie przyjrzeć się temu, co w związku z ową przestrzenią było traktowane jako akt komunikacji oraz kogo traktowano jako możliwego partnera tego aktu.

\begin{tabular}{ccc}
$\begin{array}{c}\text { JA SADZACEGO } \\
\text { ROŚLINĘ }\end{array}$ & $\begin{array}{c}\text { LUDOWA KOMPETENCJA } \\
\text { KOMUNIKACYJNA }\end{array}$ & TY \\
NADAWCA & KOMUNIKAT & ODBIORCA \\
\cline { 2 - 3 } JA ROŚLINY & $\begin{array}{c}\text { LUDOWA KOMPETENCJA } \\
\text { KOMUNIKACYJNA }\end{array}$ & $\mathrm{TY}$ \\
& &
\end{tabular}

Ilustracja 1. Schemat ludowej kompetencji komunikacyjnej - model dla aktu roślina - człowiek Źródło: opracowanie własne.

Wprowadzając istotne zawężenie jakościowe przekazów, model umożliwia ukierunkowanie badań na opis komunikacyjnego potencjału natury. Wyodrębnione w nim elementy pozwalają dostrzec najistotniejsze (zdaniem autorki) kryterium różnicujące charakter interakcji.

\section{Nadawca komunikatu}

Każdorazowo właściwym nadawcą komunikatu jest człowiek. Wyodrębnienie dwóch typów JA (ludzkiego i roślinnego) nie jest podyktowane próbą zdefiniowania autora kryjącego się za przekazaną treścią - gdyż ten jest w obu przypadkach taki sam, a wynika z chęci zróżnicowania podmiotu kodującego. JA SADZĄCEGO ROŚLINĘ to nic innego, jak JA konkretnej gospodyni, która intencjonalnie posługuje się roślinnością w obrębie przedogródka w celu porozumiewania się z innymi ludźmi. Włączając rośliny w granice swojego domowego świata, nadaje im symboliczne znaczenie. To dzięki nim niejednokrotnie utrzymuje „delikatną równowagę między potrzebą bycia stosownym a pragnieniem skuteczności” (Morreale, Spitzberg, Barge, 2008: 71). Natomiast JA ROŚLINY to metaforyczne określenie użyte dla odzwierciedlenia charakterystycznej dla mieszkańców ówczesnej wsi wiary w nadprzyrodzoną moc natury. Niezwykłość roślinności znajdowała swój wyraz między innymi w przekonaniu, że każda radość, tak jak każde nieszczęście 
powinny być zapowiedziane znakami przekazywanymi przez istoty z „tamtego" świata, a więc również i rośliny. Antropomorfizowane w ludowej mądrości drzewa, krzewy, kwiaty i zioła „komunikowały się” z ludźmi. Dzięki temu, iż anomalie związane z ich okresem wegetacyjnym miały jasno zdefiniowane przyczyny, ich wystąpienie było traktowane jako konkretny znak „pozwalający odczytać coś, co przed zmysłami człowieka jest zakryte" (Szary, 2015: 6).

\section{Odbiorca komunikatu}

Zarówno w przypadku JA SADZĄCEGO ROŚLINE, jak i JA ROŚLINY zakładam, że TY musi być różne od JA. Dla „ludzkiego” JA odbiorcami są wszystkie osoby, które spostrzegą komunikat, z wyłączeniem mieszkańców danego gospodarstwa. Natomiast dla JA „roślinnego” - przy założeniu, że inicjatorem komunikacji jest siła transcendentna - odbiorcami są w pierwszej kolejności gospodarze zagrody, w dalszej zaś mieszkańcy wsi.

\section{Komunikat}

Proces produkcji i interpretacji komunikatów, dla których nośnikiem treści była zieleń z przydomowego ogródka, był możliwy dzięki wspólnej mieszkańcom wsi wiedzy na temat roślin, w tym ich:

1) legendarnego/mitycznego pochodzenia,

2) praktycznego zastosowania,

3) właściwości leczniczych,

4) czarodziejskich mocy,

5) symbolicznego znaczenia w obrzędach,

6) obecności w motywach zdobniczych,

które to określam mianem ludowej kompetencji komunikacyjnej. Naturalnie nawet najbardziej szczegółowa wiedza o roślinności z przedogródka stanowi zaledwie jeden z wielu elementów składających się na ludową kompetencję. Odkrycie i opisanie wszystkich w ramach teorii komunikatywistycznej daje szansę na przyjrzenie się kulturze polskiej wsi z nieco innej perspektywy, jak stwierdził bowiem Edward Twitchell Hall - komunikacja to kultura, a kultura to komunikacja. 


\section{Egzemplifikacja}

Trudno precyzyjnie określić, w którym momencie do nasadzeń w przestrzeni siedliska wiejskiego dołączyły rośliny pełniące prymarnie funkcję komunikacyjną. Niewątpliwie jej zalążki obecne były od początku istnienia ozdobnych ogrodów. Samo pojawienie się w tradycyjnej chłopskiej zagrodzie kwiatowych rabatek informowało o zamożności gospodarzy. Najbiedniejsi, pochłonięci pracą na swoich i cudzych polach, nie mieli siły i czasu na nieproduktywną pracę, jaką była hodowla kwiatów. Drugą, nie mniej istotną informację niósł wygląd przedogródka. Opiekujące się nim kobiety dokładały wszelkich starań, ponieważ w oczach sąsiadów stanowit on ich atrybut. Czasami, bez wyraźnej intencji gospodyni, przedogródki zdradzały tajemnice alkowy. I tak: młode mężatki bezskutecznie starające się o potomstwo sadziły bylicę - „panie niepłodne, bylica czyni płodne” i szałwię, która „leczy niepłodność”. Wystrzegały się natomiast rumianku - „zapach rumianku czyni niepłodne i sprowadza poronienie". Kobiety przy nadziei miały ogrody pełne barwinka - „poronienia płodu broni”, dziurawca - „podkurzany ułatwia poród”, lilii - „,pręciki kwiatu ułatwiają poród”, orlików - „nasienie zażyte ułatwia poród”, ślazu - „słany pod brzemienną ułatwia poród”, a także bylicy - „do snadnego i rychłego rodzenia pożyteczna [...] plastrowana na żywocie ułatwia poród” oraz szałwii - „,polewka ułatwia poród [...] woń ułatwia poród". Wspomniany już orlik pomagał także na kłopoty małżeńskie - „niepotężność do skutku małżeńskiego przez czary utraconą przywodzi”. Wrotycz zaś róst w zagrodach, w których matki drżały o cnotę urodziwych córek - „Gdyby którą białą głowę sczarowano, iżby z gorącej miłości wszczął się jej niepokój, a iżby rozumiała, żeby była dziewka, a iżby panieństwo miała stracić, tedy się niech w tej wrotyczy myje, odejdą od niej te czary"1.

Naturalnie powyższe przesądy nie realizują założeń proponowanego modelu, w ramach którego działanie musi przebiegać według ściśle określonego schematu. Nadawca komunikatu, sadząc roślinę, świadomie podejmuje decyzję, że za jej pomocą chce przekazać konkretną informację, zakłada przy tym, że odbiorcy dysponują tą samą co on ludową kompetencją komunikacyjną. Dla zilustrowania procesu odwołam się do kilku przykładów.

Zgodnie ze staropolskim zwyczajem, gdy na świat przychodziła dziewczynka, przed domem sadzono lipę, gdy zaś chłopiec - dąb, jawor lub klon, „wiążąc w ten sposób los nowo narodzonego z losem dobrego drzewa" (Rodak-Śniecińska, 2011: 333). Liczba drzew stawała się informacją o liczbie synów i córek w zagrodzie.

Przed chatami, w których były panny na wydaniu, w przedogródkach rosły kaliny, lilie, rozmaryny, malwy, nagietki i aksamitki. Gdy młode dziewczęta chciały

1 Wszystkie zacytowane wierzenia pochodzą z wydanego w 1895 zielnika Józefa Rostafińskiego pt. Zielnik czarodziejski to jest zbiór przesqaów o roślinach (Rostafiński, 2018). 
się pochwalić, że to one, a nie ich matki dbają o ogród, sadziły słoneczniki - „słonecznik rośnie prawie w każdym ogródku domowym pielęgnowanym przez dziewczęta" (Kujawska i wsp., 2016: 473). Znano także sposoby na subtelne poinformowanie o ubóstwie. Kawaler, który szukat bogatej dziewczyny, musiał omijać zagrody, gdzie rosła dziewanna, gdyż zgodnie z przysłowiem „tam, gdzie dziewanna, niebogata (bez posagu) panna" (Kujawska i wsp., 2016: 134).

Czasami sama wiedza na temat komunikacyjnej roli kwiatów nie była wystarczająca. Obecność bylicy pospolitej w ogródku mogła informować, że córka gospodarzy dorosła do zamążpójścia, ale również mogła wskazywać, że w domu oczekiwano na śmierć - ,jak dawniej ludzie wiedzieli, kiedy mają umrzeć, a w związku z tym ten, który wkrótce miał umrzeć, nie grodzit płotów z chrustu lub jałowca, ale z bylicy" (Kujawska i wsp., 2016: 109).

Komunikacyjna rola przedogródka nie sprowadzała się tylko do wymiany informacji między gospodynią domostwa a jej sąsiadami. Mówienie o roli komunikacyjnej ogródków przydomowych wydaje mi się równie uzasadnione w odniesieniu do przekazów, które pochodzą „,bezpośrednio” od roślin. Zgodnie z ludowymi wierzeniami drzewa, krzewy, kwiaty i zioła, dzięki umiejętności oscylowania między dwoma światami, przekazują ludziom informacje pochodzące od duchów i demonów. W tym przypadku schemat wygląda następująco: odbiorca spostrzega wygląd rośliny i przypisuje mu nadprzyrodzone znaczenie. Nabyta w toku socjalizacji ludowa kompetencja komunikacyjna nie umożliwia odbiorcy odczytania komunikatu, a przyłożenie do zastanej sytuacji pasującego zabobonu, co czyni go nieświadomym nadawcą. Jednakże dostrzeżenie w nim jednocześnie nadawcy i odbiorcy stanowiłoby w pewnym stopniu znaczne uproszczenie. Po pierwsze dlatego, iż to nie on jest autorem danego wierzenia, a tylko je odtwarza, po drugie zaś jest on przekonany o jego prawdziwości. Jak w 1895 roku pisał Edward Kolbuszowski:

Lud uważa drzewa i kwiaty jako czasową cielesną osłonę duszy, jako tylko dalsze miejsce tymczasowego zatrzymania się [...] Każde prawie drzewo jest dla wieśniaka naszego niejako świątynią, bo mieszkaniem jakiegoś ducha, jakiejś tajemniczej sity, która mu już to korzyść, już to szkodę przynosi. Z uszanowaniem i czcią spogląda wieśniak na kwiaty i drzewa, bo mniema, że one są mieszkaniami duchów, bo mniema, że wyrządziwszy jaką szkodę drzewu, obrazi i na się ducha zamieszkującego je, który nań karę za to zesłać może. Każde drzewo wzbudza w nim otuchę lub bojaźń stosownie do tego, w jakie wyobraźnia jego przybrała je przymioty, jakimi zaludniata duchami - dobrymi czy złymi (Kolbuszowski, 1895: 120). 
Przydomowe ogródki dzięki lokalnym gustom w doborze roślin były wyznacznikiem odmienności regionalnej w nie mniejszym stopniu niż architektura czy strój ludowy. Różnorodność sadzonej zieleni wiązała się z różnorodnością związanych z nią wierzeń, co obrazują poniższe przykłady.

Żołędzie niemal w całej Polsce były wykorzystywane do przepowiadania pogody i przyszłego urodzaju. Ich obfitość była zapowiedzią dużych zbiorów bobu (Tarnów i Rzeszów) lub żyta (Wieliczka). Niewielka zaś liczba zwiastowała ostrą zimę i „że dziki będą ryły ziemniaki” (Tarnobrzeg). W Poznańskiem wierzono, że:

[...] jeśli we wrześniu jest pajęczyna na żołędzie, będzie zły rok. Jeśli koło niej wiele much, będzie urodzaj średni. Jeśli robaki ją poczynają toczyć, będzie rok obfity i do ożenku dobry. Pusta żołądź oznacza śmiertelność i pożary. Zbyteczny żołędzi zbiór czy też ilość oznacza mroźną zimę z mnóstwem śniegu i obfitym rybołówstwem. Jeśli jądro żołędzi twarde, będzie dużo zboża, ale zarazem morderstw i wilkołaków. Jeśli chuda żołądź, trzeba się przygotować na wielkie upały i brak wody. Wilgotne jądro zapowiada mokry rok i powodzie (Kujawska i wsp., 2016: 130).

Podobne przekonania mieli mieszkańcy województwa lwowskiego.

Rośliny potrafiły też przewidywać czyjąś śmierć. Na przykład kiedy czarny bez rosnący blisko domu zakwitał powtórnie na jesieni, odczytywano to jako znak, że umrze ktoś z domowników bądź ktoś młody i lubiany ze wsi (Szary, 2015: 7). W okolicy Pińczowa była to zapowiedź pomoru dzieci (Kujawska i wsp., 2016: 80). Natomiast gdy bez usecht wiosną, wiadomo było, że „nadchodzi susza i woda uciekać będzie ze studni” (Rodak-Śniecińska, 2011: 37).

Dużą popularnością w przepowiadaniu cieszyły się kwiaty. Wróżono z nich w sprawach radosnych i błahych oraz tych dotyczących życia i śmierci. Oto kilka przykładów: panna, która chciała się dowiedzieć, czy szybko wyjdzie za mąż, wrzucała bławatki do rozkopanego mrowiska, jeżeli te się zaczerwieniły, wróżba była pomyślna (Kujawska i wsp., 2016: 114). Pod Kłodawą zaś w wigilię św. Jana „dziewczyna wyrywa bylicę w samo południe i uważa, co pod nią znajduje, jeśli jest węgielek, wyjdzie za mąż, jeśli zaś robak, straci wianek” (Kujawska i wsp., 2016: 109). Chcąc się dowiedzieć, czy spełni się życzenie, łodyżkę dziewanny przychylano do ziemi i przyciskano ją lekko kamyczkiem, tak aby się nie złamała. Jeśli roślina o własnych siłach się podniosła, życzenie uważano niemal za spełnione (Kujawska i wsp., 2016: 138). W Chełmskiem, gdy żona niepokoiła się o los męża w wojsku „wtedy urywała gałązkę Sedum telephium [rozchodnika - przyp. aut.] i zatykała ją w drzewie lub budynku. Potem zaś po dziewięciu dniach sprawdzała 
wygląd rośliny, jeśli była ona jeszcze świeża i zielona, mąż żył, jeśli zaś gałązka uschła, był chory albo umart" (Kujawska i wsp., 2016: 286).

Obok licznych zastosowań barwinka znalazło się i takie, które odnosito się do jego czarodziejskich mocy. Nad Niemnem stosowano go do wróżenia o zdrowiu i życiu chorego. Jego liście wrzucone do garnka z wodą stawiano na progu chaty bądź pod tóżkiem. „Jeżeli liście pożółkną i opadną na dno, chory umrze, jeżeli pozostają zielonymi i pływają na powierzchni, wyzdrowieje" (Kujawska i wsp., 2016: 76).

Komunikowanie się ludności dawnej wsi ze zantropomorfizowaną roślinnością, stanowiące wyraz ich głębokiej więzi z naturą, było sprawdzonym i skutecznym sposobem na „oswojenie tych sfer życia, które wymykały się ludzkiemu panowaniu nad światem" (Szary, 2015: 6).

\section{Dalsze perspektywy badawcze}

Zaproponowany w niniejszym artykule model ludowej kompetencji komunikacyjnej, obejmujący akty: roślina (człowiek) - człowiek i roślina (siła nadprzyrodzona/ ludowa wiara) - człowiek, stanowi narzędzie, na podstawie którego zamierzam prowadzić dalsze badania. Pierwszy ich etap będzie polegać na zebraniu informacji dotyczących roli zieleni z bezpośredniego otoczenia człowieka, począwszy od XVIII wieku, a skończywszy na czasach współczesnych. Ze względu na regionalny charakter wierzeń obserwację ograniczę do jednego obszaru kulturowego: ziemi podkarpackiej. Opracowana w powyżej zaprezentowany sposób jednostka materiałowa będzie stanowiła bazę dla diachronicznych badań nad komunikacyjną rolą roślinności przydomowej oraz ludową kompetencją komunikacyjną.

Analiza na płaszczyźnie komunikatywizmu będzie analizą powierzchowną, wyjaśniającą, z jakimi typami zjawisk komunikacyjnych mamy do czynienia oraz ustalającą ich standardowość lub niestandardowość. Kolejna analiza - przeprowadzona na płaszczyźnie kulturowej - będzie stanowiła już analizę pogłębioną, zmierzającą do wyczerpującego opisu, uwzględniającego wszystkie możliwe czynniki kształtujące przekaz informacji za pośrednictwem roślinności.

\section{Bibliografia}

Awdiejew A., Habrajska G. (2012), Komponowanie sensu w procesie odbioru komunikatów, Łódź: Wydawnictwo Primum Verbum. Kolbuszowski E. (1895), Rośliny w wierzeniach ludu: Bez „,'Lud. Organ Towarzystwa Ludoznawczego we Lwowie”, t. 1(4, 5), s. 119-123. Koprowska-Głowacka A. (2016), Magia ludowa z Pomorza i Kujaw, Gdynia: Wydawnictwo Region. 
Kujawska M., Łuczaj Ł., Sosnowska J., Klepacki P. (2016), Rośliny w wierzeniach izwyczajach ludowych. Słownik Adama Fischera, Wrocław: Polskie Towarzystwo Ludoznawcze.

Marcyński K. (2017), Kompetencja komunikacyjna. Studium medioznawcze, Warszawa: Wydawnictwo Naukowe Uniwersytetu Kardynała Stefana Wyszyńskiego.

Morreale S.P., Spitzberg B.H., Barge J.K. (2008), Komunikacja między ludźmi. Motywacja, wiedza i umiejętności, Warszawa: Wydawnictwo Naukowe PWN.

Moszyński K. (1934), Kultura ludowa Słowian. Kultura duchowa, cz. II, t. I, Kraków: Polska Akademia Umiejętności.

Moszyński K. (1939), Kultura ludowa Słowian. Kultura duchowa, cz. II, t. II, Kraków: Polska Akademia Umiejętności.

Pisarek W. (2008), Wstęp do nauki o komunikowaniu, Warszawa: Wydawnictwa Akademickie i Profesjonalne.

Rodak-Śniecińska A. (red.) (2011), Na początku było drzewo. Magiczne, lecznicze i smakowe właściwości drzew, Warszawa: Wydawnictwo Baobab.

Rostafiński J. (2018), Zielnik czarodziejski to jest zbiór przesqdów o roślinach, Sandomierz: Wydawnictwo Armoryka.

Sadowska J., Winkler A. (2015), Tradycyjne ogródki przydomowe, Łódź: Ogród Botaniczny, Zarząd Zieleni Miejskiej.

Simonides D. (2010), Dlaczego drzewa przestały mówić? Ludowa wizja świata, Opole: Wydawnictwo Nowik.

Szary A. (2015), Bieszzzadzkie motywy roślinne. Między światem żywych a krainq zmarłych, Rzeszów: Wydawnictwo Carpathia.

Tomiccy J. i R. (1975), Drzewo życia. Ludowa wizja świata i człowieka, Białystok: Ludowa Spółdzielnia Wydawnicza.

Wiszniewski A. (2003), Sztuka mówienia, Katowice: Wydawnictwo Videograf II.

Zadrożyńska A. (1985), Powtarzać czas poczq̨tku, Warszawa: Wydawnictwo Spółdzielcze. 